\title{
FROM THE ENGLISH DEPARTMENT
}

\author{
Livio Dobrez
}

Gordon Briscoe's appreciation of Kevin Gilbert is nothing if not boots-and-all. I assume that Aboriginal people can cope with this kind of thoroughly iconoclastic outspokenness and debate. If they can, it is all to the good. The Aboriginal cause is too important, not only to Aborigines but to everyone in this country, to be side-tracked by, however wellmeaning, fetish or mystique. We need to keep the reality of Aboriginal lives and struggles before us, not Pellegrini plaster-cast replicas. Having said that, I have every intention of defending Gilbert, whom I knew and respected, against some of the comments of my friend Briscoe. In so doing I naturally fall into Briscoe's trap and in part validate his argument, which is that Gilbert is an icon manufactured by whites. Catch 22 - provided Briscoe's argument is right in the first place.

The argument, as I understand it, goes something like this. No special case should be made out for Gilbert as Aboriginal. Indeed, it may well be that no special case of this sort should be made out for anyone, since we are all subject to socio-economic laws whose determination is prior to determination by race. Thus Gilbert is a rural worker, a 'cherry picker', before he is black. His life requires analysis and critique in the light of class and economics, something which Briscoe believes is lacking in Gilbert's own writing. There is the added complication that, for Briscoe, Gilbert is hardly Aboriginal at all; rather, Aboriginality is that identity he constructs for himself during those deadening prison years. So two mystiques are in operation: the dubious notion of Aboriginality, at least in the form Briscoe labels 'proto-nationalist', and Gilbert's own self-construct. After which a third mystique comes into play: non-Aboriginal people find it politically expedient to construct a black icon, Gilbert as Aboriginal Hero. In reality, says Briscoe, Gilbert is a figure in many ways marginal to the black struggle, best understood when demystified, at which point he appears as rural labourer, journalist, theologian, populist, proto-nationalist and surrealist. I intend to comment on this with emphasis on Gilbert's literary achievement and on the way in which I think Aboriginal cultural products such as writing and art should be 'read'.

It seems to me right and proper to question pious assumptions as Briscoe does, but I remain sceptical about many of the conclusions. In his personal life Gilbert is taken to task for choosing to be a fringe-dweller and, more pointedly, for killing his first wife. Both acts implicitly relate to Briscoe's larger argument about Gilbert's separatist, even supposedly racist, attitudes. It is as if Briscoe's Gilbert chooses to be non-white, first by refusing the social assimilation of the welfare system, then by an actual and symbolic murder, and finally by a willed metamorphosis - white to black - while in prison. These are harsh judgements and only someone with an intimate knowledge of Gilbert could possibly comment on them. I note, however, that Briscoe's quotation of the passage from Living Black which describes the killing runs as follows: 'I was pissed, she was tired and despairing and I grabbed a rifle ....' In fact the actual passage on p. 243 of the 1977 Allen Lane and the 1978 Penguin editions reads: 'I was pissed, she was tired and despairing and grabbed a rifle ....' Did anyone other than Gilbert know exactly what took place in the

Livio Dobrez is Reader in English and convenor of the BA (Australian Studies) at the ANU. He teaches contemporary theory as well as Australian and modern European writing. 
middle of that terrible night? Whatever it was, I doubt it was morally straightforward. Is the omisson of the subject-I from the text a mere slip or a complex Freudian one? Is it a slip at all?

On the question of Aboriginality, there may well be at least an element of truth in Briscoe's portrait of the man who constructs an identity behind bars. But is the identity any the less genuine for that? Certainly there is no inherent contradiction between being a 'cherry picker' and being Aboriginal. But of course Briscoe's article sees Aboriginality itself as a theological construct requiring deconstruction: again, Gilbert's personal life cannot be separated from his social message. For Briscoe Aboriginality does not obtain in reality; Aboriginal people lack homogeneity; they have never been and are not now a nation; they are in fact part of the Australian nation. Black identity, in short, has more to do with haves and have-nots than a 'religion of difference' or a 'black nationalism'.

I would not for a moment dispute Briscoe's economic and class observations. Likewise it may well be that ideas of sovereignty pushed to separatist extremes have little basis in Aboriginal political reality. But we cannnot be sure that it will always be so. Certainly talk of 'black Israels' seems particularly unfortunate in retrospect, and in more ways than one. But, no matter how internally divided, did Aboriginal society identify itself as 'Australian' on January 26, 1988? I would have thought not, and understandably not. That does not mean that one can talk glibly about an Aboriginal nation, but the phrase 'protonationalism' or 'national conscious-ness' (as distinct from fully-fledged 'nationalism') seems by no means inappropriate to describe the enormous upsurge of black activism in a number of fields, cultural and political, over the past two or so decades. If there is no such thing as Aboriginality, that is, no shared proto-nationalism, how do we explain the emergence of a front at least sufficiently united to bargain with government in 1993? Or even something like the Barunga Statement, now in New Parliament House? That document combines, in visual and written form, the aspirations of groups ranging from Arnhem Land to the Western Desert. Thus Aboriginality, however internally heterogeneous, has a basis in reality it did not have once, even if its character is more negative than positive, that is, even if it is based on a shared experience of suffering and oppression rather than on an experience of cultural sameness.

It is true that this common political experience of suffering may be also related back Briscoe thinks spuriously and in idealized fashion - to a common socio-theological tradition. I agree that such a tradition can only with difficulty be made to produce the totalizing identity of Aboriginality. Rather it is inherently pluralist and fragmenting: it produces tight-knit Aboriginal groupings but not the proto-nationalist monolith 'Aboriginality'. However, it need not follow from this that old pluralist socio-theological structures cannot be adapted to serve the needs of a growing sense of unified Aboriginality. Aboriginal societies were always adaptive, and they have had to be especially adaptive since 1788. Can't we see Gilbert's views, however affected by white anthropologists, as one more creative example of radical adaptation, rather than as, in Briscoe's words, mere 'traditionalism'? And in this connection it is enough to recall that Gilbert's formula of 'give us land, an economic start in the form of compensation and then leave us alone to make our own decisions' has proved anything but a political dead end in the post-Mabo negotiations of 1993 .

I do not think that Because a White Man'll Never Do It and Living Black, which outline much of the position critiqued by Briscoe, represent 'journalism' in the derogatory sense. Perhaps in some ways Gilbert is, as Briscoe insists, an alienated individual on the margin of Aboriginal society. Prophets, however, have been known to come from Galilee, and one might equally argue that Gilbert's complex between-two-worlds position gave him 
some strategic advantages. It may have tempted him to romanticize the socio-theological past, to hunt for a spirit or essence of Aboriginality. But one can be excessively Feuerbachian about this. Gilbert was in precisely the right situation to appreciate the significance of spiritual traditions and the shock to the social system produced by their demise.

To come to the issue of Gilbert's literary achievement. Briscoe calls Gilbert a surrealist and I take the comment to be pejorative. Actually, European surrealism - and its Australian counterpart in the late thirties and early forties - saw itself as intensely politically revolutionary. I have no difficulty, however, in conceding that surrealism's 'revolution' operated largely, if not entirely, in the sphere of political fantasy. So if Briscoe wants to suggest by the term the apolitical futility of Andre Breton's proverbial individual who discharges his pistol randomly into the crowd, then I accept his usage. I don't accept, as already indicated, that Gilbert's was a fantasy politics. But it is on the literary aspect of Gilbert's supposed surrealism that I wish to focus at this point. You can reasonably argue that there are surreal (if not exactly surrealist) elements in Gilbert's writing, as, for example, in the opening of The Cherry Pickers. Comparable elements can be found in Merritt's The Cake Man and in sixties Australian plays by people like Hibberd and Buzo and Romeril, not to mention the so-called Theatre of the Absurd in postwar Europe, particularly the plays of Genet, Ionesco and Pinter. But I would prefer to say that the Prologue to Gilbert's play takes the form of ritualized action - whose effect is rather different from the surreal. Even here there are realist elements, mixed up with the nonrealist: the colloquial language of I AM, for example, as he fashions Aboriginal people. As for the rest of the play, with the partial exception of Tommlo's and Zeena's regenerative dance, it is emphatically in a realist mode. Whether its depiction of the behaviour and speech of the pickers is accurate, I cannot judge with any certainty, but I assume authenticity, given that Gilbert had first-hand experience of people like these characters. In any case, whatever its authenticity, the play remains unambiguously realist in concept, that is, realist in the literary-genre sense.

What about the poetry of People Are Legends? Here Briscoe's charge is that it is 'little more than ranting' and this is followed up with the larger point, that we apply a double standard in literary judgement, one - rigorous - for non-Aboriginal writing, another uncritically empathizing and consequently patronizing - for Aboriginal writing. So it appears that Briscoe is thinking of poetry other than Gilbert's: poetry, for example, like some of that collected by Gilbert in the anthology Inside Black Australia. For what it is worth, my view is that some of Gilbert's poems work well while others have a rhetorical feel about them. I like poems like 'Love? Country Party Style', 'Fair Swap', 'Maureen' and many others which seem to me to rely on colloquial immediacy and whose rhythms are, appropriately, those of the traditional folk song or protest ballad. I particularly like 'Birth Control for Blacks' and 'Granny Koori': witty poems with a nice bite. But, the literary dinosaur will ask, do you like these as much as your favourite Australian poet, Michael Dransfield? Or, if it comes to that, Shakespeare? In short, is it as good as Dransfield or Shakespeare? Why answer this question? It is clearly political, since it asks one to rank cultural artefacts so as to rank cultures themselves. In any case, individual likes and dislikes are of less than momentous significance. One can leave judgement to history, secure in the knowledge that history may (or then again may not) judge accurately.

A more interesting question seems to me to be that of the way in which Aboriginal writing as a whole asks to be read. Briscoe's approach is refreshing insofar as it refuses to fetishize difference, that is, refuses the argument, so often put forward in contemporary criticism, that one cannot read across the boundaries of culture, gender, sexuality and the 
like. White cannot claim to read black, or male claim to read female, or straight read gay and so on. Briscoe - and this is consistent with his desire not to mystify Aboriginality insists on a single standard and therefore implicitly gives the non-Aboriginal reader access to the space of Aboriginal writing. I find this an attractive aspect of his thinking, but there are some requisite provisos and I would like to theorize the whole issue by suggesting that we do in fact require a specific hermeneutics of Aboriginal writing. It may be true that we can all (with widely varying degrees of comprehension, naturally) read Aboriginal writing. But this is not to say that all writing should be placed in the one category, that is, that there is no such thing as a distinct category of Aboriginal writing. Any given body of cultural production, insofar as it has any distinctiveness, requires a particular way of reading if it is to be adequately understood. In other words it requires a particular interpretation, a particular hermeneutics. Aboriginal writing is no exception. This seems an obvious point to make, but it was not necessarily grasped by white reviewers of Inside Black Australia and I am not sure it is properly allowed for in Briscoe's argument. You can't just say: one criterion for all. Nor can you simply ask that black writing, Gilbert's included, be read as 'art', which amounts to the same thing.

Surprisingly, given the socialist orientation of his article, Briscoe accepts the aestheticizing of cultural production, that is, he accepts categories like 'art' and 'literature' when these are better viewed as the result of a historical and ideological process about which there may be justified suspicion. The aestheticizing impulse seems particularly distorting in the case of Aboriginal writing and art. After all, pre-contact culture referred itself not to aesthetic but to religious categories. And contemporary Aboriginal culture - as exemplified by everything from regional bark painting, sculpture, canvas acrylics, dance and song to urban art, rock music, theatreand writing - is surely better understood in politico-religious than in aesthetic terms. Of course there are exceptions, since to a degree the cultural production of urban Aborigines has been aestheticized and is seen as 'art' by its producers. But only to a degree. The introduction to the recent Paperbark anthology prioritizes the political, not the aesthetic, though it does not quite resolve a certain ambiguity in this respect. Gilbert's introduction to Inside Black Australia also puts politics centre-stage. The Aesthetic is simply not, as most people believe, a universal category. Rather it is culture-specific. That means that insistence on its universal application - to all cultures or even to the one culture at different times - expresses cultural arrogance. A proper hermeneutics of Aboriginal writing requires adequate contextualization, otherwise hermeneutic understanding (in the classical sense of Verstehen ) will fall short of the mark. I don't understand and so cannot properly judge a Balgo acrylic, say by Wimmitji, without realizing that is is a spiritual map and so a title-deed of land, that is, without grasping its politico-religious context. Mutatis mutandis, the same is true of 'Granny Koori'. It's not just a 'poem', just 'art'.

There is another aspect to all this. Gilbert's and indeed black writing in general should not be aestheticized on the grounds that it is in English and to a large extent employs originally European categories (modes such as realism or genres such as 'poetry' or 'drama' or 'prose'). With so-called Post-Colonial critics, I would argue that when non-Aboriginal forms or language are appropriated by Aboriginal writers something new is brought into being, the forms cease to be simply European, the language ceases to be simply English. Isn't this obvious in the case of Wimmitji's picture? The canvas and the acrylic are nonAboriginal, but it does not follow that we can assimilate the result to the European. In like manner, a hermeneutics of black writing requires us to approach the Aboriginal text as a reorientation and transformation of received forms. Of course, Gilbert's language is English. But in order to do interpretative justice to the poems, don't we need to take 


\section{FROM THE ENGLISH DEPARTMENT}

account of the way in which they bend and alter received usage? The unthinking will say that it is bad English. In fact, like, in varying degrees, all Aboriginal writing, it signals, for those able to recognize it, a phase in the development of creole speech. This may be more plainly evident in Rastafarian Jamaican English or in Aboriginal-English pidgin than in the language of a writer as removed from black traditions as Gilbert. But it is evident even there. Gilbert the editor of Inside Black Australia is right in arguing against the reading of Aboriginal verse in the light of non-Aboriginal 'antecedents' (xviii). More markedly than Australian English in general, Aboriginal English cannot be conceptualized as a branch of an existing tree. It is already another tree, though one not without relation to the other. To stress the relation rather than uniqueness expresses a political wish to prioritize the English or European component. What I have termed a proper or adequate hermeneutics will not ignore this component, but it will put it in perspective. Given that until recently readings of Aboriginal writing by non-Aborigines have been blind to anything other than non-Aboriginal criteria, it seems time to redress the balance.

Briscoe represents Gilbert as a near-white writer writing for whites. I have no doubt that, like many Aboriginal writers, Gilbert, while writing primarily for Aborigines, glanced over his shoulder at the ever-present non-Aboriginal witness: white activists, white literary pundits, white authorities of all kinds, in short, white society. But if he did not write and speak to and for Aborigines, he wrote and spoke to and for no one - except perhaps himself. That is too ungenerous a suggestion and in any case it is scarcely borne out by the facts.

Your turn again, Gordon.

Australian National University 